\title{
Familial Adenomatous Polyposis (FAP) and Other Polyposis Syndromes
}

\author{
Rodney J. Scott \\ Newcastle Bowel Cancer Research Collaborative, University of Newcastle and the Hunter Medical Research Institute, Newcastle, NSW, Australia
}

Key words: familial, adenomatous, hamartomatous, polyposis, genetics

Corresponding author: Rodney J. Scott, Discipline of Medical Genetics, Faculty of Health, University of Newcastle, NSW 2308, Austalia.Phone+61 24921 4974,fax+6124921 4253,e-mail: Rodney.Scott@hunter.health.nsw.gov.au

\begin{abstract}
There have been significant advances in our knowledge about the molecular changes that precede and accompany the development of inherited predispositions to colorectal cancer. In this review the clinical relationship to the molecular changes associated with the polyposis syndromes is presented. The aim is to put into context the diverse findings that have been shown to be associated with the development of colorectal cancer in persons who harbor a predisposition to develop disease at unusually early ages. The main focus will be on familial adenomatous polyposis as it serves as a model disease and is the most extensively studied of all of the polyposis syndromes. In addition some information is provided that explains the relationship between a germline change in one gene and what consequences that can have for a particular cell and the development of disease.
\end{abstract}

\section{Introduction}

Since the advent of human genome project there has been a revolution not only in our understanding of cellular function but also with respect to how we view all types of disease, from psychiatric illness, coronary heart disease, neurological disorders, to cancer. No longer can we assume that pathological changes can be diagnosed in terms of descriptive differences between normal and diseased tissue. Recent molecular biological developments are now providing better and earlier disease definition than previously thought possible. This trend will continue such that accurate diagnosis of disease will be easier to perform and consequently more specific treatment strategies applied. With the identification of genes associated with disease more knowledge is also gained by a better understanding of the cellular events that cause overt illness.

For the first time in the history of medicine we are now able to predict in certain groups of patients (with a very high degree of accuracy), who is more likely to become ill. Unfortunately, society may not be prepared for such a radical change as ongoing discussions concerning the benefits of presymptomatic diagnosis continue to dominate the introduction of these new methodologies. Nevertheless, this trend in preventative medicine will continue and grow as it offers for the patient the best prognosis should they be identified as being at risk of developing the disease.

With respect to cancer, significant advances have been made in our understanding of how it develops and slowly the molecular changes that precede overt disease are being unravelled. It is now considered a multifaceted disease, which involves diverse mechanisms such as DNA repair, cell signalling and apoptosis, all of which contribute to the development of the malignant cell. With respect to this review, all of these mechanisms can be shown to contribute to colorectal cancer in persons who carry a genetic predisposition.

\section{Genetics of the Polyposis Syndromes}

There is abundant clinical and pathological evidence, which suggests that colorectal cancer develops in a sequential manner through a series of events that can be followed during the progression of the disease from early adenoma through to metastatic disease. The molecular events that are associated with 
initiation and progression of the disease are gradually being dissected. As the molecular characterization of colorectal cancer continues new mechanisms of initiation and progression are becoming evident. In this review a description of the current knowledge of polyposis development shall be presented with a special emphasis on familial adenomatous polyposis (FAP).

Colorectal cancer is the second most common malignancy in Europe and North America with similar incidence rates for both men and women. Epidemiological studies suggest that environmental factors play a significant role in the etiology of disease [1]. For example the incidence of colorectal cancer $(\mathrm{CRC})$ is very much higher in countries where the diet is rich in fat and low in fibre $[2,3]$. Furthermore, there exist a number of distinct genetic syndromes, which predispose persons to the development of CRC, some of which are listed in Table 1. From this table there are two genetic entities (Familial Adenomatous Polyposis Coli and Hereditary Non-Polyposis Colorectal Cancer) which predispose persons to an extremely high risk of developing CRC at a young age. In addition to CRC, other malignancies and symptoms tend to aggregate in these families implying that the affects of the predisposition are not restricted to the colon alone. Interestingly, not all signs of disease are necessarily malignant nor are they always readily apparent, a good example being the presence of osteomas and supernumerary teeth in FAP. An often-overlooked aspect of any hereditary disease is that persons carrying a genetic predisposition do not initially have CRC but they have the susceptibility to develop it. This implies that other genetic and environmental factors can and do influence disease expression. Therefore, it must always be borne in mind that there are essentially two factors that influence the expression of disease, one being genetic and the other environmental. As a general rule, genetic influences occur early in life whereas only later do environmental effects become more apparent (as is the case for colorectal cancer occurring in persons who have no apparent genetic predisposition to disease). However, both effects interact with one another such that genetic factors may be minimised by avoiding certain environmental risks or by actively seeking preventative agents. The trigger that initiates the development of CRC is not known but it is believed that the colonic environment plays a crucial role. Recent epidemiological studies have revealed for instance that moderate dose aspirin has a protective affect with respect to CRC incidence in the general population [4-6]. When considering genetic predispositions to CRC similar environmental influences can inhibit the development of disease as is the case with nonsteroidal anti-inflammatory drugs, which include such agents as aspirin and Sulindac [7]. Thus CRC is not in itself inherited but the susceptibility, which favours its development, is.

Since genetic predispositions to colorectal cancer provide a unique insight into the cellular and biochemical changes that occur during disease development, many studies have been performed to investigate the earliest genetic changes that occur during the transition from normal cellular growth to neoplasia in familial cancer and compare them to those occurring in sporadic disease.

\section{The Genetic Model of CRC}

The development of CRC from normal tissue through hyperplasia, adenomas, pre-invasive, invasive and finally metastatic disease is much more apparent than in any other common malignancy such as breast or lung cancer. The molecular genetics of CRC are probably the best understood of the common malignancies, as it is relatively easy to obtain premalignant and malignant tissue at various stages of neoplastic development. This and the fact that there exist familial forms of CRC has allowed for detailed molecular investigations to be performed. For the remainder of this review a description of the molecular genetic events that appear to underlie the development of the adenomatous polyposis syndromes shall be presented as well as some information on the development of hamartomatous polyposis.

One of the most significant findings concerning CRC was the discovery not only in sporadic CRC but also in FAP that it appeared to arise from the clonal expansion of a subset of cells that had acquired a particular growth advantage after a somatic mutation [8]. Additional support for the clonal expansion of cells in human CRC came from parallel studies in mice, which were fed dietary carcinogens and subsequently developed CRC [9]. Such findings are in direct contrast to normal mucosa, which is polyclonal even in the normal mucosa of patients with FAP [10]. Taken together these results imply that a somatic mutational event is necessary before adenoma development can proceed. This is of particular relevance with respect to inherited forms of CRC as they too require an additional somatic mutational event before adenoma development implying a "second hit", which is consistent with Knudsons" "Two Hit" hypothesis [1 11]. The "two-hit" theory implies that the initiation of cancer is not a single process and that two independent events should occur before disease becomes overt. The two hit model has been extensively modified since the discovery of tumor suppresser genes as the original hypothesis implied that the second hit was at an entirely different site to that of the first [12]. 


\section{Familial Adenomatous Polyposis}

Over recent years significant advances have been made in our understanding of the molecular genetic events associated with CRC due to intensive investigations into FAP. This is an autosomal dominantly inherited disease that accounts for approximately $1 \%$ of all CRC cases observed and has a prevalence of approximately 1 in 10,000 [13, 14]. Phenotypically, FAP is characterised by the presence of hundreds to thousands of small adenomatous polyps, which if left untreated would almost certainly develop into colorectal cancer. Characteristically, FAP has a very high penetrance with virtually all gene carriers presenting with colonic polyposis by their fourth decade and without intervention succumbing to it by the middle of their fifth decade of life. The site of colonic adenoma development is not restricted to particular parts of the colon, however, there is a tendency for colorectal cancer to develop distally. Heterogeneity does, nevertheless, exist such that milder and more severe forms of the disease (referred to as Attenuated Adenomatous Polyposis Coli, AAPC and the Flat Adenoma Syndrome or FAS) have been described which can make for a difficult clinical diagnosis [15-17]. Lower polyp number, later age of onset and slower disease progression distinguishes AAPC whereas FAS presents with multiple flat adenomas throughout the colon and is also associated with slower disease development and progression and later average age of onset.

In addition to colonic symptoms, there occur other extra-colonic manifestations, which appear to be associated with FAP as shown in Table 2. The association of osteomas, epidermoid cysts and polyposis continues to be referred to as Gardner's syndrome as it was first described by Eldon Gardner over 50 years ago [18]. Most FAP patients who have been treated for their colonic disease tend to succumb to extra-colonic disease rather

Table 1. Inherited Predispositions to Colorectal Cancer

\begin{tabular}{|c|c|c|}
\hline \multicolumn{3}{|l|}{ Syndromes with preexisting polyposis } \\
\hline Disease & Gene & Disease Phenotype \\
\hline Familial Adenomatous Polyposis & APC & colonic polyposis \\
\hline Gardner's Syndrome & APC & colonic polyposis in association with extra colonic lesions \\
\hline Oldfield's Syndrome & APC & colonic polyposis in association with sebaceous cysts \\
\hline Turcot's Syndrome* & APC & $\begin{array}{l}\text { malignant tumors of the central nervous system } \\
\text { in association with polyposis of the colon }\end{array}$ \\
\hline \multicolumn{3}{|c|}{ Syndromes with preexisting hamartomatous polyps } \\
\hline Peutz-Jeghers syndrome & LKB1/STK1 1 & abnormal pigmentation on the lips and buccal mucosa \\
\hline $\begin{array}{l}\text { Ruvalcaba-Myhre-Smith syndrome } \\
\text { (Bannayan-Riley-Ruvalcaba Syndrome) }\end{array}$ & Unknown & macrocephaly, pigmented macules on the penis \\
\hline Juvenile polyposis & SMAD4 (DPC) & cystic hamartomatous polyps \\
\hline Cowden's syndrome & PTEN & $\begin{array}{l}\text { multiple hamartomatous lesions, primarily on the } \\
\text { mucocutaneous tissue) }\end{array}$ \\
\hline \multicolumn{3}{|l|}{ Syndromes without preexisting polyposis } \\
\hline $\begin{array}{l}\text { Hereditary non-polyposis colorectal cancer } \\
\text { (Lynch Type I and Type II syndromes) }\end{array}$ & $\begin{array}{l}\text { hMSH2 } \\
\text { hMLH1 } \\
\text { hPMS1 } \\
\text { hPMS2 } \\
\text { hMSH6 }\end{array}$ & few if any polyps, CRC tends to be site specific \\
\hline Muir-Torre's Syndrome\# & hMSH2 & $\begin{array}{l}\text { Lynch type II syndrome with dermatological } \\
\text { lesions and laryngeal cancer }\end{array}$ \\
\hline Turcot's Syndrome* & $\begin{array}{l}\mathrm{hMSH} 2 \\
\mathrm{hMLH} 1\end{array}$ & Glioblastoma Multiforme Astrocytoma grades 3 or 4 \\
\hline
\end{tabular}

*Turco'ts Syndrome is a special case, see below. 
than colorectal cancer [19]. Today, CRC development can be prevented by prophylactic removal of the colon. As a consequence of surgical intervention patients live longer but now are faced with the prospect of developing other manifestations of the disease which are much more resistant to treatment. Examples of which include desmoid disease and upper gastrointestinal adenocarcinomas, which often do not respond to current treatment approaches. A full understanding of the mechanisms that underlie the development of extra-colonic disease in FAP could provide some insight towards a better rationale of treatment as current methods appear to be ineffective especially when considering desmoid disease. Not all manifestations of the disease are necessarily malignant and indeed some of them may be useful in identifying asymptomatic persons who could be at risk of developing CRC. An example of such a symptom is shown in Table 2 , it being congenital hypertrophy of the retinal pigment epithelium (or CHRPE) that was first described in 1980 [20], which is a feature of both Gardner's syndrome and FAP. CHRPEs can be identified ophthalmologically and can occur as single or multiple lesions on the retina, which do not lead to any major disturbances in vision. The symptom of CHRPEs is interesting as it segregates with polyposis in some families. Initially, it was believed that this manifestation of the disease could be used as a non-invasive marker for determining the carrier status of non-symptomatic persons within any given family [21]. It became evident that this symptom could not be relied upon for an accurate diagnosis as not all FAP patients even within the same family may necessarily present with this sign. It remains useful, however, in those families where segregation of this trait can be linked to CRC development.

Table 2. Symptoms observed in FAP

\begin{tabular}{l}
\hline Symptoms observed in FAP \\
\hline Polyposis \\
\hline Hepatoblastoma \\
\hline Desmoids \\
\hline Congenital Hypertrophy of the Retinal Pigment Epithelium (CHRPE) \\
\hline Periampullary carcinomas \\
\hline Osteomas \\
\hline Epidermoid Cysts \\
\hline Small Intestinal carcinomas \\
\hline Gastric Polyps \\
\hline Dental Abnormalities \\
\hline
\end{tabular}

\section{Syndromes Associated with Familial Adenomatous Polyposis}

\section{Oldfield's Syndrome}

Oldfield's syndrome is similar to polyposis except for the additional symptom of multiple sebaceous cysts [22]. It is not clear if this is a chance association or a true extra-colonic manifestation of FAP, however, it is of note that it is quite a common feature in some mouse models of the disease (R. Fodde, personal communication). This syndrome is extremely rare.

\section{Turcot's Syndrome}

Turcot first described the association of colorectal polyposis and brain tumors in 1959 where two teenage siblings were described with polyposis of the colon and malignancies of the central nervous system. One of the patients was diagnosed with a medulloblastoma involving the spinal cord and the other a cerebral glioblastoma multiforme and a pituitary tumor [23]. Since this first observation more than 120 cases have been reported with differing degrees of colonic disease severity, some cases only presenting with one adenomatous polyp and others with typical polyposis. Recently, a molecular basis for Turcot's syndrome has been proposed based on the finding that two inherited colorectal cancer predispositions are involved, namely FAP and hereditary nonpolyposis colorectal cancer (HNPCC). Turcot's syndrome associated with FAP appears to be somewhat specific with respect to the development of central nervous system tumors. Medulloblastomas appear to be the prominent brain lesion in persons harboring APC germline mutations, however, anaplastic astrocytomas and ependymomas have been reported [24]. Little is known about the molecular events that give rise to brain tumors in FAP or HNPCC.

\section{Familial Infiltrative Fibromatosis (FIF)}

For many years FIF (more commonly known as desmoid disease) was considered a separate entity to FAP. In 1996 one report was published linking mutations in the APC gene to FIF [25]. A second report was published by another group, which confirmed the notion that some APC gene mutations resulted in a much greater predisposition to desmoid disease than others [26]. The mutation site in the APC gene, which correlated with desmoid disease was identified as lying towards the $3^{\prime}$ end of the gene. Of the four families Scott et al. [25] investigated 3 which were found to 
harbor an identical mutation and were also discovered by haplotype analysis to be related to on another. The fourth family did not appear to harbor any germline mutation in the APC gene, suggestive of a second gene associated with this disorder. In the initial reports, colonic disease was not described as a feature, but subsequent to the report by Eccles et al. [26] microadenomas were identified indicating a mild colonic phenotype suggestive of an increased risk of colorectal cancer (K. Nugent, personal communication).

\section{Searching for the APC Gene and its Function}

The first advance in the understanding of the molecular nature of FAP occurred after the discovery by Herrera et al. [27] of a mentally retarded male who presented with Gardner's syndrome. Cytogenetic analysis revealed that the patient had an interstitial deletion of the long arm of chromosome 5q. Within 5 years of Herrera's discovery the gene responsible for FAP was identified simultaneously by two groups and is now commonly known as the $\underline{\text { Adenomatous }}$ Polyposis $\underline{\text { Coli }(A P C)}$ gene [28-31]. The APC gene contains an 8538 bp open reading frame and consists of 18 exons [32]. The first three exons are not transcribed and the next 14 are relatively short with the eighteenth being one of the largest exons so far described for any gene, spanning over three quarters of the entire coding sequence (6577 bp) of the gene. When the gene was initially reported only fifteen exons were described (14 small exons and 1 large exon), after which most researchers describe the gene as being composed of 15 exons [29]. There exist several differentially spliced versions of the APC gene, one splice variant is associated with exon 9 and this may be linked to the milder disease phenotype that FAP patients present with when they harbor mutations in this exon [33].

In colonic epithelium the APC gene appears to be present in two different forms, which gives rise to two mRNA transcripts, one being approximately 300 bases longer than the other with the largest being the most abundant [29,34]. In contrast, in the oesophagus, there is only a relatively short transcript present, which may provide a clue as to why this site appears to be spared from polyp development [32].

Localization of the full length APC protein indicates that it is neither nuclear or membrane bound and that it appears in the non-soluble fraction of the cell. Truncated forms of the protein appear both in the soluble and insoluble fractions of the cell, implying that they may be oligomerizing with the full-length protein [28, 30]. The $\mathrm{N}$-terminal region is responsible for APC homodimerization, and most mutant APC molecules retain the capacity to dimerize with wild type APC both in vivo and in vitro $[35,36]$. The second significant feature of the APC gene product is its interaction with the adherins junction proteins called catenins, to date at least three proteins have been identified that interact with APC, these being $\alpha$-catenin, $\beta$-catenin and plakoglobin (a $\gamma$-like catenin) which all bind to E-cadhedrin [37]. Some of the repeat amino acid sequences in the central region of the APC protein are postulated to be responsible for this interaction $[35,38]$. Evidence suggests that catenins are involved in the transmission of adhesion signals and in the anchorage of adherins junctions to the actin cytoskeleton [39]. Furthermore, the APC protein has been shown to associate with microtubules as shown by its binding to tubulin in vitro leading to the promotion of microtubule assembly $[40,41]$. Mutated forms of the APC gene that lack the carboxy terminus of the protein failed to elicit similar responses providing some evidence in favour of microtubule binding.

Together, information concerning the structure and molecular association of the APC protein indicate that it is associated with the cytoskeleton and in regulation of contact inhibition [42]. APC has been shown to bind to $\beta$-catenin, suggesting a role in mediating extracellular communication from cadherin to the nucleus. Importantly, too much $\beta$-catenin in the nucleus will result in apoptosis, which would tend towards a decreased incidence of tumor formation therefore closer attention needs to be focused on the role of mutant APC alleles and how they modulate cellular control (see below). Other proteins are also implicated in the formation and regulation of the APC-catenin complex. Regulation of APC- $\beta$-catenin complex assembly appears to be mediated by a protein similar to GSK3 $\beta$ (glycogen synthase kinase $3 \beta$ ) which binds directly to the complex [43]. Other proteins have also been identified that also bind to particular amino acid sequences, most notably the Drosophila Discs large tumor suppresser protein (DLG), which is believed to play a role in regulating cell cycle progression and neuronal function [44].

\section{Colorectal Cancer Development and the APC Gene}

Evidence that the APC gene is involved in the development of colorectal cancer can be summarised as follows: deletions of chromosome $5 q$ result in the APC phenotype. Persons harboring an APC germline mutation invariably develop colorectal cancer, which is usually preceded by a florid polyposis. Restoration of chromosome 5 by microcell mediated chromosome transfer results in a reversion of a tumor phenotype in colorectal cancer cell lines thus indicating that a gene or 
set of genes on this chromosome can suppress colonic tumor development $[45,46]$. Introduction of the APC gene to colon cancer cell lines causes a reversion in tumor phenotype [47]. Together this evidence indicates strongly that the APC gene is a tumor suppresser gene and is directly involved in colorectal cancer development.

Phenotypic variation between patients with different mutations in the APC gene can be explained by the "JustRight" signalling model proposed by Albuquerque et al. [48]. In this model it is proposed that partially functional alleles of APC are sufficient to poorly regulate the levels of $\beta$-catenin. Sufficient accumulation of $\beta$-catenin occurs within the nucleus to activate certain key transcription factors that promote tumor development but insufficient levels are reached to trigger apoptosis. The model is based on findings, which show that different sites of mutation in the APC gene influence the type of second hit on the wild type allele prior to tumor formation. Germline mutations that occur between codons 1,194 and 1,392 appear to be almost exclusively associated with somatic loss of the wild type allele in contrast to other germline mutations, located outside of this region, which appear to be linked to somatic mutations in the wild type APC allele [49].

An alternative explanation for the mild phenotype observed in patients harboring mutations $5^{\prime}$ of codon 157 is the presence of a second initiation codon at a position upstream of codon 157 which could remove any problems associated with mutations within the $5^{\prime}$ region of the gene [50].

\section{Other Genes \\ Associated with Colorectal Cancer in Familial Adenomatous Polyposis}

Until recently there has been only circumstantial evidence to suggest that other genetic changes could give rise to a disease with a phenotype similar to FAP. Initially, this was demonstrated using linkage analysis that clearly showed some families displaying that an atypical polyposis phenotype were not linked to chromosome $5 q 21$. Very recently a gene associated with base excision repair can, if mutated in the homozygous state, result in a phenotype similar to FAP, although the number of colorectal adenomas does appear to be slightly less than that expected in FAP associated with germline mutations in the APC gene. The gene in question is the MYH gene, located on Chromosome 1 p32-34, and it differs from APC and indeed most other genetic predispositions to colorectal cancer identified to date in that it appears to be associated with an autosomal recessive disease inheritance pattern [5153]. The recessive inheritance pattern of the disease is in essence consistent with other familial predispositions to $C R C$ in that disease development only occurs once there is a complete loss or change of function.

\section{Modifier Genes that may Influence the Likelihood of Colorectal Cancer Development}

Although some phenotypic variation may be due to differences in mutant alleles of the APC gene there can be considerable differences in disease presentation even among family members who carry identical germline APC mutations. For instance, some family members may present with only a few colonic polyps whereas others have thousands and still others may manifest a variety of other non-gastrointestinal tumors such as osteomas, sarcomas, and desmoids [15, 54]. Such variation within families may be due to varying degrees of environmental stress (such as diet), a genetic background (i.e. modifier genes) or both. Unfortunately, it is difficult to determine what influence environmental or genetic modifiers have in human pedigrees. Since the identification of the APC gene and the presence of a naturally occurring autosomal dominantly transmitted mouse equivalent of FAP (known as the Multiple Intestinal Neoplasia or Min mouse) harboring a germline mutation in the mouse Apc gene (written Apc to designate mouse) questions concerning disease expression and penetrance could be addressed.

Min mice thus provide a model system for studying human FAP and in particular for identifying genes that can modify the phenotype caused by the Apc mutation. The advantage of using the Min mouse is that it is derived from an inbred strain of mice (C57BL/6J-Min/+). When bred pure the average number of tumors in each mouse is about 29. When Min mice were crossed with another inbred strain of mouse, $A K R$, the average number of tumors dropped to 6 per animal [55]. This finding suggested that the AKR mouse carries alleles that can act in a dominant fashion to modify the tumorigenic affect of Min. Genetic mapping studies identified a locus on mouse chromosome 4 that strongly modifies tumor multiplicity termed Mom-1 (for Modifier of Min). Interestingly, Mom- 1 lies in a region of synteny with the human chromosomal segment 1 p35-36, a region that shows frequent somatic loss of heterozygosity in a variety of human tumor types, including colon [56]. In 1995, a candidate was identified, the secretory phospholipase A2 gene (sPLA2), which is believed to account for about $50 \%$ of the variation seen in Min mice [57]. In Min mice there is low sPLA2 activity whereas in AKR mice its activity is very high. Secretory phospholipase A2 is one of several enzymes involved in generating arachidonic acid and lysophosphatidic acid. Arachidonic acid is the rate-limiting 
step in the synthesis of prostaglandins and leukotrienes [58] and is therefore in low abundance in the C57BL/6JMin/+ mouse but its levels are high and hence protective in the AKR mouse. This evidence creates a dilemma as there are several studies indicating that non-steroidal antiinflammatory drugs (NSAIDs) can decrease the level of specific prostaglandin E2 in the colonic mucosa [59] by inhibiting cyclooxygenase.

Other polymorphic genes exist apart from sPLA2, which may also alter the likelihood of either disease development or expression. It is to be expected that any gene that is capable of affecting disease is likely to be represented within the population in several different forms at relatively high frequency, such examples include $\mathrm{N}$-acetyl transferase and glutathione-S-transferase.

\section{Prevention and Therapy of FAP}

Disease prevention in persons suffering from FAP has and will continue to be prophylactic removal of the colon before progression occurs. An often quoted age for this operative procedure is twenty years of age. Recently, it has become recognised that certain non-steroidal antiinflammatory drugs (NSAIDs) such as Sulindac (Clinoril) and aspirin may be beneficial in reducing polyp size and number [59] and that there may even be site specific affects [7]. The action of NSAIDs and aspirin is believed to work by inhibiting the enzyme cyclo oxygenase, which in turn leads to a decrease in the formation of prostaglandins. Decreasing the levels of prostaglandins appears to have a protective effect with respect to colonic disease development. The exact mechanism by which NSAIDs operate is, however, unknown as there appears to be more to it than merely inhibition of arachidonic acid synthesis and hence prostaglandins formation. In addition, there is reason to believe that dietary resistant starch may also lead to a reduction of polyp number and size [60]. It must be stressed, however, that NSAIDs are no substitute for total colectomy in FAP. There are reports of cancer development in patients taking NSAIDs even when significant polyp regression had occurred [61].

\section{Syndromes with Preexisting hamartomatous Polyps}

\section{Peutz-Jeghers syndrome}

Peutz-Jeghers syndrome is an autosomal dominantly inherited condition affecting both sexes equally, which predisposes to the development of gastrointestinal adenocarcinoma. Penetrance is incomplete and often the genetic defect develops as a result of a spontaneous mutation [62]. A unique type of gastrointestinal hamartoma, mucocutaneous pigmentation, as well as extra-gastrointestinal neoplasms characterizes the disease. A typical feature of Peutz-Jeghers hamartomas is a smooth muscle core derived from the muscularis mucosae and extending into the polyp. The mucosa covering the polyp is similar to that found in the region of the gut in which it occurs $[62,63]$. A second feature, which is one of the most significant characteristics of the disease, is the presence of mucocutaneous pigmentation. Pigmented macules occur most often on the lips and buccal mucosa and less commonly on the eyelids and dorsal surfaces of fingers and soles of the feet. The presence of these symptoms is not usually detected at birth but appears after the first or second year of life. As the patients age the lip pigmentation fades whereas buccal pigmentation does not.

Sufficient evidence exists in the literature to indicate clearly that patients with Peutz-Jeghers syndrome are at increased risk of developing adenocarcinoma of the gastrointestinal tract. The majority of these lesions are located in the stomach, duodenum, and colon. The prevalence of $\mathrm{Gl}$ carcinoma is not accurately known but it is estimated to be between $2 \%$ and $20 \%$. Debate remains as to whether carcinoma in this syndrome arises from either malignant transformation of a hamartomatous polyp, coexisting adenoma or de novo [64-66]. In addition to $\mathrm{Gl}$ tract tumors, extra-intestinal tumors are also observed in patients with this syndrome. The prevalence of extra-intestinal tumors varies from between $10 \%$ and $30 \%$ with the most commonly reported tumors being pancreas, breast and reproductive organs [67-70]. The incidence of pancreatic cancer is about 100 times that expected and occurs at unusually early ages [67, 69, 70-73]. An increased frequency of breast cancer is also observed and is usually bilateral and ductal in origin $[68,70,74-76]$. Neoplasms of the reproductive tract such as adenoma malignum (a uterine cancer) have also been reported in Peutz-Jegher's patients. Benign microscopic ovarian tumors designated ovarian sex cord tumors with annular tubules are also considered to be present in most women with this syndrome [77-81]. The genetic locus for PJS was identified in 1996 and found to lie on chromosome 19p13.3, however, not all families typed were linked to this locus and a second site was identified at position 19q13.4 [82]. A putative gene was identified which mapped to the Ch 19p13.1 region, termed initially LKB1, which was homologous to the serine threonine kinase STK 11 [83, 84]. Since the identification of STK 11 several studies have shown that germline mutations in this gene appear to account for up to half of all families $[85,86]$. 


\section{Ruvalcaba-Myhre-Smith syndrome (macrocephaly, pigmented macules on the penis)}

This rare syndrome originally included a small group of patients with features of macrocephaly, pigmented genital lesions, intestinal polyposis and an autosomal dominant inheritance pattern [87, 88] Intestinal hamartomatous polyposis is seen in $45 \%$ of patients and appears to be limited to the distal part of the colon. Additional features of the disease include subcutaneous visceral lipomas and hemangiomas [89]. No defined genetic locus has been described.

\section{Juvenile polyposis}

Genetically, juvenile polyposis is not precisely defined. Approximately $25 \%$ of cases are transmitted as an autosomal dominant trait [90-95]. Juvenile polyps are usually pedunculated hamartomas and can be seen in both children and adults. The hamartomas may ulcerate, bleed or cause obstruction, with time they tend to self amputate. Patients with juvenile polyposis are at increased risk of developing malignant intestinal tumors (especially colorectal cancer), most offen diagnosed in the 2nd or 3rd decade [96-103]. Precancerous lesions have been well documented within juvenile polyps suggesting that carcinomas arise out of these lesions [63]. In addition to colorectal lesions, carcinoma of the stomach, duodenum and pancreas has also been reported in juvenile polyposis patients. Epidemiological evidence suggests that family members of juvenile polyposis patients are also at increased risk of developing gastrointestinal malignancies. Recently the SMAD4 (or DPC) gene has been implicated in the development of this syndrome. The function of SMAD4 is associated with the mediation of signals from transforming growth factor (TGF) beta and related ligands such that SMAD4 mediates TGF-beta-stimulated gene transcription [104].

\section{Cowden's Disease}

This multiple hamartomata syndrome is a genodermatosis characterized by hamartomas and neoplasms of ectodermal, mesodermal and endodermal origin affecting multiple organs and organ systems [105, 106]. To date around 160 cases have been reported in the literature. The syndrome is an autosomal dominantly inherited disease and occurs primarily in Caucasians. Mucocutaneous lesions are present in all patients and are considered a hallmark of the disease. Facial papules, oral mucosal papilomatoses, acral keratoses and multiple sclerotic fibromas appear to be the most characteristic features of the disease [106-1 11 1]. The majority of cases are diagnosed between the ages of 30 and 40 years. The most consistent clinical features are mucocutaneous lesions associated with a variety of thyroid gland abnormalities, breast carcinoma and hamartomatous polyposis of the gastrointestinal tract [106-108, 112].

Hamartomatous polyps of the gastrointestinal tract occur in approximately $40-70 \%$ of patients with Cowden's disease. Histopathologically, the appearance of gastrointestinal polyps is difficult to classify as a wide variety of findings have been reported [109, 113-117]. The majority, however, are now recognised as hamartomas [63, 106, 107, 112, 113]. The multiple hamartoma syndrome (MHS) hamartomas differ from the Peutz-Jeghers hamartoma by several distinctive features. The MHS hamartoma is usually sessile, smaller and have less exophytic and arborizing proliferation of the muscularis mucosae $[63,113]$.

Thyroid abnormalities are the most frequent extracutaneous abnormality, occurring in approximately $65 \%$ of patients. Goitres and adenomas are the most common lesions and affect equally men and women $[106,108]$. Thyroid follicular adenocarcinoma has also been reported in 3-12\% of patients, all of which have been found in women $[106,107]$. Recently, a genetic locus for Cowden's disease has been identified on chromosome 10q22-23 by a genomic wide screening strategy and loss of heterozygosity analysis of tumors that comprise part of the spectrum of the disease [118]. The PTEN gene is a putative protein tyrosine phosphatase [119] that is essential for embryonic development and tumor suppression [120]. Several patients with Cowden's disease have now been shown to harbor germline mutations in the PTEN gene [121] thus providing strong evidence for it being the predisposing genetic factor involved in the transmission of this disease from generation to generation.

\section{Conclusion}

It is widely accepted that colorectal cancer develops as a result of a progressive series of genetic alterations in oncogenes and tumor suppresser genes. In an inherited predisposition such as FAP, it is the germline mutation of the APC gene that initiates disease development and any genetic events occurring thereafter are associated with disease progression. In addition, the genetic background of the affected persons plays a major role in disease presentation. It is only now becoming apparent that familial predispositions to colorectal cancer preceded by either hamartomatous or adenomatous polyposis are best described as monogenetic diseases but are influenced by diverse genetic and environmental factors. With 
increased knowledge of the molecular mechanisms underlying the development of inherited predispositions to colorectal cancer will better and more targeted therapies and prevention strategies be developed.

\section{References}

1. Vatn MH, Hoff G, Clausen OPF. Epidemiology and histopathogenesis of colorectal cancer. Eur J Cancer Prev 1991; 1, suppl 2: 5-12.

2. Willet WC, Stampfer MJ, Colditz GA. Relation of meat fat and fiber intake to the risk of colon cancer in a prospective study among women. New Engl J Med 1990; 323: 1664-72.

3. Boland CR, Kolars JC. Fiber and colon cancer: the weight of the evidence. Gastroenterology 1992; 103: 1964-7.

4. Thun MJ, Namboodiri MM, Calle EE, Flanders WD, Heath CW. Aspirin use and risk of fatal cancer. Cancer Res 1993; 53: 1322-7.

5. Thun MJ, Namboodiri MM, Heath CW Jr. Aspirin use and the reduced risk of fatal colon cancer. N Eng J Med 1991; 325: 1593-6.

6. Giovannucci E, Egan KM, Hunter DJ, Stampfer MJ, Colditz GA, Willett WC, Speizer FE. Aspirin and the risk of colorectal cancer in women. N Eng J Med 1995; 333: 609-14.

7. Guldenschuh I, Ammann R, Hurlimann R, Muller A, Mullhaupt B, Dobbie Z, Zala F, Flury R, Seelentag W, Meyenberger C, Fried M, Spiegelman AD, Scott RJ. Sulindac in familial adenomatous polyposis: Is there an enhanced effect on regression of adenomas in the proximal colon. Dis Colon \& Rectum 2001; 44: 1090-7.

8. Fearon ER, Hamilton SR, Vogelstein B. Clonal analysis of human colorectal tumors. Science 1987; 238: 193-7.

9. Ponder BAJ, Wilkinson MM. Direct examination of the clonality of carcinogen-induced colonic epithelial dysplasia in chimeric mice. J Natl Cancer Inst 1986; 77: 967-76.

10. Fearon ER, Jones PA. Progressing toward a molecular description of colorectal cancer development. FASEB 1992; 6: 2783-90.

11. Knudson AG, Meadows AT, Nichols WW, Hill R. Chromosomal deletion and retinoblastoma. New Engl J Med 1976; 295: $1120-3$.

12. Knudson AG. Hereditary cancer oncogenes and antioncogenes Cancer Res 1985; 45: 1437-43.

13. Bishop DT, Thomas HJW. The genetics of colorectal cancer. Cancer Surveys 1990; 4: 585-604

14. Bülow S. Familial polyposis coli. Danish Med Bull 1987; 34: 1-15.

15. Spirio L, Otterud B, Stauffer D, Lynch H, Lynch P, Watson P, et al. Linkage of a variant or attenuated form of adenomatous polyposis coli to the adenomatous polyposis coli APC locus. Am J Hum Genet 1992; 51: 92-100.

16. Dobbie Z, Spycher M, Hürlimann R, Ammann R, Ammann T, Roth J, Müller A, Müller Hi, Scott RJ. Mutational analysis of the first 14 exons of the adenomatous polyposis coli APC gene. Eur J Cancer 1994; 30A 1 1: 1709-13.

17. Lynch HT, Smyrk TC, Lanspa SJ, Jenkins JX, Lynch PM, Cavalieri J, Lynch JF. Upper gastrointestinal manifestations in families with hereditary flat adenoma syndrome. Cancer 1993b; 71: 2709-14.

18. Gardner EJ. A genetic and clinical study of intestinal polyposis a predisposing factor for carcinoma of the colon and rectum. Am J Hum Genet 1951 ; 3: 167-76.

19. Nugent KP, Phillips RKS, Hodgson SV, Cottrell S, Smith-Ravin J, Pack K, Bodmer WF. Phenotypic expression in familial adenomatous polyposis: partial prediction by mutation analysis. Gut 1994; 35: 1622-3.

20. Blair NP, Trempe CL. Hypertrophy of the retinal pigment epithelium associated with Gardner's syndrome. Am J Opthalmol 1980; 90: 661-7.
21. Burn J, Chapman P, Delhanty J, Wood C, Lalloo F, CachonGonzalez MB, Tsioapra K, Church W, Rhodes M, Gunn A. The UK Northern Region genetic register for familial adenomatous polyposis coli: use of age of onset congenital hypertrophy of the retinal pigment epithelium and DNA markers in risk calculations. J Med Genet 1991; 28: 289-96.

22. Ingram JT, Oldfield MC. Hereditary sebaceous cysts. Brit Med J 1937; 1: 960-3.

23. Turcot J, Després J-P, St Pierre F. Malignant tumors of the central nervous system associated with familial polyposis of the colon: report of two cases. Dis Colon Rectum 1959; 2: 465-8.

24. Hamilton SR, Liu B, Parsons RE, Papadopoulos N, Jen J, Powell SM, Krush AJ, Berk T, Cohen Z, Tetu B, Burger PC, Wood PA, Taqi F, Booker SV, Petersen GM, Offerhaus GJA, Tersmette AC, Giardiello FM, Vogelstein B, Kinzler KW. The molecular basis of Turcot's syndrome. N Eng J Med 1995; 33213: 839-47.

25. Scott RJ, Froggatt NJ, Trembath RC, Evans DG, Hodgson SV, Maher ER. Familial infiltrative fibromatosis desmoid tumors MIM 135290 caused by recurrent 3' APC gene mutation. Hum Mol Genet 1996; 5: 1921-4.

26. Eccles DM, van der Luiit R, Breukel C, Bullman H, Bunyan D, Fisher A, Barber J, du Boulay C, Primrose J, Burn J, Fodde R. Hereditary desmoid disease due to a frameshift mutation at codon 1924 of the APC gene. Am J Hum Genet 1996; 59: $1193-201$.

27. Herrera L, Kakati S, Gibas L, Pietrzak E, Sandberg AA. Gardner syndrome in a man with an interstitial deletion of $5 \mathrm{q}$. Am J Med Genet 1986; 25: 473-6.

28. Groden J, Thliveris A, Samowitz W, Carlson M, Gelbert L, Albertsen $H$, Joslyn G, Stevens J, Spirio L, Robertson M, Sargeant L, Krapcho K, Wolff E, Burt R, Hughes JP, Warrington J, McPherson J, Wasmuth J, Le Paslier D, Abderrahin H, Cohen D, Leppert M, White R. Identification and characterization of the familial adenomatous polyposis coli gene. Cell 1991; 66: 589-600.

29. Joslyn G, Carlson M, Thliveris A, Albertson H, Gelbert L, Samowitz W, Groden J, Stevens J, Spirio L, Robertson M, Sergeant L, Krapcho K, Wolff E, Burt E, Hughes JP, Warrington J, McPherson J, Wasmuth J, Le Paslier D, Abderrahim H, Cohen D, Leppert M, White R. Identification of deletion mutations and three new genes at the familial polyposis locus. Cell 1991; 66: 601-13.

30. Kinzler KW, Nilbert MC, Su L-K, Vogelstein B, Bryan TM, Levy DB, Smith KJ, Preisinger AC, Hedge P, McKechnie D, Finniear R, Markham A, Groffen J, Boguski MS, Altschul SF, Haar A, Ado H, Miyoshi Y, Midi Y, Nishisho I, Nakamura Y. Identification of FAP locus genes from chromosome 5q21. Science 1991; 253: 661-5.

31. Nishisho I, Nakamura Y Miyoshi Y, Midi Y, Ado H, Haar A, Koyama K, Utsunomiya J, Baba S, Hedge P, Markham A, Krush AJ, Petersen G, Hamilton SR, Nilbert MC, Levy DB, Bryan TM, Preisinger AC, Smith KJ, Su LK, Kinzler KW, Vogelstein B. Mutations of chromosome $5 q 21$ genes in FAP and colorectal cancer patients. Science 1991; 253: 665-9.

32. Samowitz WS, Thliveris A, Spirio LN, White R. Alternatively spliced adenomatous polyposis coli APC gene transcripts that delete exons mutated in attenuated APC. Cancer Res 1995; 55: 3732-4.

33. Scott RJ, Meldrum C, Crooks R, Spigelman AD, Kirk J, Tucker K, Koorey D, the Hunter Family Cancer Service 2001 Familial adenomatous polyposis: more evidence for disease diversity and genetic heterogeneity. Gut 48: 508-14.

34. Lebovitz RM, Albrecht S. Molecular biology in the diagnosis and prognosis of solid and lymphoid tumors. Cancer Invest 1992; 10: 399-416.

35. Su L, Johnson KA, Smith KJ, Hill DE, Vogelstein B, Kinzler KW. Association between wild type and mutant APC gene products. Cancer Res 1993; 53: 2728-31.

36. Joslyn G, Richardson DS, White R, Alber T. Dimer formation by 
an N-terminal coiled coil in the APC protein. Proc Natl Acad Sci USA 1993; 90: $11109-13$

37. Rubinfeld B, Souza B, Albert I, Munemitsu S, Polakis P. The APC protein and $\mathrm{E}$-cadherin form similar but independent complexes with $\beta$-catenin and plakoglobin. J Biol Chem 1995; 270: 5549-55

38. Rubinfeld B, Souza B, Albert I, Müller O, Chamberlain SH, Masiarz FR, Munimitsu S, Polakis P. Association of the APC gene product with $\beta$-catenin. Science 1993; 262: 1731-4.

39. Kemler R. From cadherins to catenins: cytoplasmic protein interactions and regulation of cell adhesion. Trends Genet 1993; 9: 317-21

40. Smith KJ, Levy DB, Maupin P, Pollard TD, Vogelstein B, Kinzler KW. Wild-type but not mutant APC associates with the microtubule cytoskeleton. Cancer Res 1994; 54: 3672-5.

41. Munemitsu S, Souza B, Müller O, Albert I, Rubinfeld B, Polakis P. The APC gene product associates with microtubules in vivo and promotes their assembly in vitro. Cancer Res 1994; 54: 3676-81.

42. Bright-Thomas RM, Hargest R. APC $\beta$-Catenin and hTCF-4; an unholy trinity in the genesis of colorectal cancer. Eur J Surg Oncol 2003; 29: 107-17

43. Rubinfeld B, Albert I, Porfiri E, Fiol C, Munemitsu S, Polakis P. Binding of GSK3 $\beta$ to the APC- $\beta$-Catenin complex and regulation of complex assembly. Science 1996; 272: 1023-6.

44. Matsumine A, Ogai A, Senda T, Okumura N, Satoh K, Baeg G-H, Kawahara T, Kobayashi S, Okada M, Toyoshima K, Akiyama T. Binding of APC to the human homolog of the Drosophila discs large tumor suppresser protein. Science 1996; 272: 1020-3

45. Tanaka K, Oshimura M, Kikuchi R, Seki M, Hayashi T, Miyaki $M$. Suppression of tumorigenicity in human colon cancer cells by introduction of normal chromosome 5 or 18. Nature 1989; 349: 340-2

46. Goyette MC, Cho KR, Fasching CL, Levy DB, Kinzler KW Paraskeva C, Vogelstein B, Stanbridge EJ. Progression of colorectal cancer is associated with multiple tumor suppresser gene defects but inhibition of tumorigenicity is accomplished by correction of any single defect via chromosome transfer. Mo Cell Biol 1992 ; 12: 1387-95

47. Groden J, Joslyn G, Samowitz W, Jones D, Bhattacharyya N, Spirio L, Thliveris A, Robertson M, Egan S, Meuth M, White R. Response of colon cancer cell lines to the introduction of APC a colon specific tumor suppressor gene. Cancer Res 1995; 55: 1531-9.

48. Albuquerque $C$, Breukel C, van der Luijt, Fidalgo P, Lage P, Slor FJ, Leitao CN, Fodde R, Smits R. The "just-right" signaling model: APC somatic mutations are selected based on a specific leve of activation of the beta-catenin signaling cascade. Hum Mol Genet 2002; 11 : 1549-60

49. Lamlum H, Ilyas M, Rowan A, Clark S, Johnson V, Bell J, Frayling I, Efstathiou J, Pack K, Payne S, Roylance R, Gorman P, Sheer D, Neale K, Phillips R, Talbot I. Bodmer W, Tomlinson I. The type of somatic mutation at APC in familial adenomatous polyposis is determined by the site of the germline mutation: a new facet to Knudson's "two-hit" hypothesis. Nat Med 1999; 5: 1071-5.

50. Heppner-Goss K, Trzepacz C, Tuohy TM, Groden J. Attenuated APC alleles produce functional protein from internal initiation. Proc Natl Acad Sci USA 2002; 99: 8161-6.

51. Al-Tassan N, Chmiel NH, Maynard J, Fleming N, Livingston AL, Williams GT, Hodges AK, Davies DR, David SS, Sampson JR, Cheadle JP. Inherited variants of MYH associated with somatic $\mathrm{G}: \mathrm{C} \rightarrow \mathrm{T}: \mathrm{A}$ mutations in colorectal tumors. Nat Genet 2002; 30 227-32.

52. Jones S, Emmerson P, Maynard J, Best JM, Jordan S, Williams GT, Sampson JR, Cheadle JP. Biallelic germline mutations in $\mathrm{MYH}$ predispose to multiple colorectal adenoma and somatic $\mathrm{G}: \mathrm{C} \rightarrow \mathrm{T}:$ A mutations. Hum Mol Genet 2002; 11: 2961-7.
53. Sieber $O M$, Lipton L, Crabtree $M$, Heinimann K, Fidalgo $P$, Phillips RK, Bisgaard ML, Orntoft TF, Aaltonen LA, Hodgson SV, Thomas HJ, Tomlinson IP. Multiple colorectal adenomas classic adenomatous polyposis and germ-line mutations in $\mathrm{MYH}$. N Engl J Med 2003; 348: 791-9.

54. Leppert M, Burt R, Hughes JP, Samowitz W, Nakamura Y, Woodward S, Gardner E, Lalouel J-M, White R. Genetic analysis of an inherited predisposition to colon cancer in a family with a variable number of adenomatous polyps. New Engl J Med 1990; 904-8.

55. Moser AR, Dove WF, Roth KA, Gordon JI. The MIN multiple intestinal neoplasia mutation: its effects on gut epithelium cell differentiation and interaction with a modifier system. J Cell Biol 1992; 116: 517-26.

56. Dietrich WF, Lander ES, Smith JS, Moser AR, Gould K, Luongo C, Borenstein N, Dove W. Genetic identification of Mom-1 a major modifier locus affecting Min-induced intestinal neoplasia in the mouse. Cell 1994; 75: 631-9.

57. MacPhee M, Chepenik KP, Liddeli RA, Siracusa LD, Buchberg AM. The secretory phospolipase A2 gene is a candidate for Mom 1 locus a major modifier of APC ${ }^{\text {min }}$-induced intestinal neoplasia. Cell 1995; 81: 957-66.

58. Glaser KB, Sung A, Baver J, Weichman BM. Regulation of eicosanoid biosynthesis in the macrophage. Involvement of protein tyrosine phosphorylation and modulation by selective protein tyrosine kinase inhibitors. Biochem Pharmacol 1993; 45: 711-21.

59. Rao CV, Rivenson A, Simi B, Zang E, Kelloff G, Reddy BS. Chemoprevention of colon carcinogenesis by sulindac, a nonsteroidal anti-inflammatory agent. Cancer Res 1995; 55 : 1464-72.

60. Burn J, Chapman PD, Eastham EJ. Familial adenomatous polyposis. Arch of Dis in Childhood 1994; 71: 103-7.

61. Thorson AG, Lynch HT, Smyrk TC. Rectal cancer in FAP patient after sulindac. Lancet 1994; 343: 180

62. Buck JL, Harned RK, Lichtenstein JE, Sorbin LH. Peutz-Jeghers syndrome. Radiographics 1992; 12: 365-78

63. Jass JR, Sobin LH, Watanbe H. A world health organization's histologic classification of gastrointestinal tumors. A commentary on the second edition. Cancer 1990; 66: 2162-7.

64. Niimi K, Tromoda H, Furusawa M, Hayashi I, Okumura Y. PeutzJeghers syndrome associated with adenocarcinoma of the cecum and focal carcionomas in hamartomatous polyps of the colon: a case report. Jpn J Surg 1991; 21 : 220-3.

65. Visvanathan V, Thambidorai CR, Myint H. Do dysplastic and adenomatous changes in large bowel hamartomas predispose to malignancy? A report of two cases. Ann Acad Med Singapore 1992; $21: 830-2$.

66. Laughlin EH. Benign and malignant neoplasms in a family with Peutz-Jeghers syndrome; a study of three generations. South Med J 1991; 84: 1205-9.

67. Utsunomiya J, Gocho H, Miyanaga E, Hamaguchi E, Kashimure A, Aoki N, Komatsu I. Peutz-Jeghers syndrome: its natural course and management. Johns Hopkins Med J 1975; 136: 71-82.

68. Linos DA, Dozois RR, Dahlin DC, Bartholomew LG. Does PeutzJeghers syndrome predispose to gastrointesnal malignancy? A later look. Arch Surg 1981; 116: 1182-4.

69. Spigelman AD, Murday V, Phillips RK. Cancer and the PeutzJeghers syndrome. Gut 1989; 30: 1588-90.

70. Giardiello FM, Welsh SB, Hamilton SR, Offerhaus GJA, Gittelsohn AM, Booker SV, Krush AJ, Yardley JH, Luk GD. Increased risk of cancer in the Peutz-Jeghers syndrome. N Eng J Med 1987; 316: 1511-14

71. Konishi F, Wyse NE, Muto T, Sawada T, Morioka Y, Sugimura $H$, Yamaguchi K. Peutz-Jeghers polyposis associated with carcinoma of the digestive organs Report of three cases and review of the literature. Dis Colon Rectum 1987; 30: 790-9. 
72. Thatcher BS, May ES, Taxier MS, Bonta JA, Murthy L. Pancreatic adenocarcinoma in a patient with Peutz-Jeghers syndrome - a case report and literature review. Am J Gastroenterol 1986; 81: 594-7.

73. Bowlby LS. Pancreatic adenocarcinoma in an adolescent male with Peutz-Jeghers syndrome. Hum Pathol 1986; 17: 97-9.

74. Burdick D, Prior JT, Scanlon GT. Peutz-Jeghers syndrome: a clinicopathologic study of a large family with a ten-year followup. Cancer 1983; 16: 854-67.

75. Trau H, Schewach-Millet M, Fisher BK, Tsur H. Peutz-Jeghers syndrome and bilateral breast carcinoma. Cancer 1982; 50: 788-92.

76. Lehur PA, Madarnas P, Devioede G, Perey BJ, Ménard DB, Hamade N. Peutz-Jeghers syndrome Association of duodenal and bilateral breast cancers in the same patient. Dig Dis Sci 1984; 29: 178-82.

77. Chen Kl. Female genital tract tumors in Peutz-Jeghers syndrome. Hum Pathol 1986; 17: 858-71

78. Yamazaki S, Katayama I, Yohezeki H, Hishioka K. Reproductive tract tumors in Peutz-Jeghers syndrome. Br J Cancer 1993; 128: 466-7.

79. Podczaski E, Kaminski PF, Pees RC, Singapuri K, Sorosky JI. PeutzJeghers syndrome with ovarian sex cord tumor with annular tubules and cervical adenoma malignum. Gynecol Oncol 1991, 42: 74-8.

80. Young RH, Dickersin GR, Scully RE. A distinctive ovarian sex cord tumor causing sexual precocity in the Peutz-Jeghers syndrome, Am J Surg Pathol 1982; 7: 233-43.

81. Herruzo AJ, Redondo E, Perez de Avila I, Aleman M, Menjon S. Ovarian sex cord tumor with annular tubules and Peutz-Jeghers syndrome. Eur J Gynaecol Oncol 1990; 11: 141-4.

82. Mehenni $H$, Blouin JL, Radhakrishna U, Bhardwai SS, Bhardwai K, Dixit VB, Richards KF, Bermejo-Fenoll A, Leal AS, Raval RC, Antonarakis SE. Peutz-Jeghers syndrome: confirmation of linkage to chromosome 19p133 and identification of a potential second locus on 19q134. Am J Hum Genet 1997; 61: 1327-1334.

83. Hemminki A, Markie D, Tomlinson I, Avizienyte E, Roth S, Loukola A, Bignell $G$, Warren W, Aminoff $M$, Hoglund P, Jarvinen $H$, Kristo P, Pelin K, Ridanpaa M, Salovaara R, Toro T, Bodmer W, Olschwang S, Olsen AS, Stratton MR, de la Chapelle, Aaltonen LA. A serine/threonine kinase gene defective in Peutz-Jeghers syndrome. Nature 1998; 391: 184-7.

84. Jenne DE, Reimann H, Nezu J, Friedel W, Loff S, Jeschke R, Muller O, Back W, Zimmer M. Peutz-Jeghers syndrome is caused by mutations in a novel serine threonine kinase. Nat Genet 1998; 18: 38-43.

85. Nakagawa H, Koyama K, Miyoshi Y, Ando H, Baba S, Watatani M, Yasutomi M, Matsuura N, Monden M, Nakamura Y. Nine novel germline mutations in STK1 1 in ten families with PeutzJeghers syndrome. Hum Genet 1998; 103: 168-72.

86. Scott RJ, Crooks R, Meldrum CJ, Thomas L, Smith CJ, Mowat D, McPhillips M, Spigelman AD. Mutation analysis of the STK1 1/LKB1 gene and clinical characteristics of an Australian series of PeutzJeghers syndrome patients. Clin Genet 2002; 62: 282-7.

87. Foster MA, Kilcoyne RF. Ruvalcaba-Myhre-Smith syndrome: a new consideration in the differential diagnosis of intestinal polyposis. Gastrointest Radiol 1986; 11: 349-50.

88. Diliberti JH, Weleber RG, Budden S. Ruvalcaba-Myhre-Smith syndrome: a case with probable autosomal dominant inheritance and additional manifestations. Am J Med Genet 1983; 15: 491-5

89. Gorlin RJ, Cohen MM Jr, Condon LM, Burke BA. Bannayan-RileyRuvalcaba syndrome. Am J Med Genet 1992; 44: 307-14.

90. Snover DC. Cowden's disease. A letter. Surgery 1987; 101 : 119-20.

91. Haggitt RC, Reid BJ. Hereditary gastrointestinal polyposis syndromes. Am J Surg Pathol 1986; 10: 871-87.
92. Bussey HJR, Veale AMO, Morson MC. Genetics of gastrointestinal polyposis. Gastroenterology 1978; 74: 1325-30.

93. Smilow PC, Pryor CA, Swinton NW. Juvenile polyposis coli. A report of three patients in three generations. Dis Colon Rectum 1966; 9: 248-54

94. Sachatello CR, Pickman JW, Grace JT Jr. Generalized juvenile gastrointestinal polyposis. A hereditary syndrome. Gastroenterology 1970; 58: 699-708.

95. Cox KL, Frates Jr RC, Wong A, Gandhi G. Hereditary generalized juvenile polyposis associated with pulmonary arteriovenous malformation. Gastroenterology 1980; 78: 1566-70.

96. Goodman ZD, Yardley JH, Milligan FD. Pathogenesis of colonic polyps in multiple juvenile polyposis. Report of a case associated with gastric polyps and carcinoma of the rectum. Cancer 1979; 43: 1906-13.

97. Longo WE, Touloukian RJ, West AB Ballantyne GH. Malignant potential of juvenile polyposis coli. Report of a case and review of the literature. Dis Colon Rectum 1990; 33: 980-4.

98. Giardiello FM, Hamilton SR, Kern SE, Offerhaus GJ, Green PA, Celano P, Krush AJ, Booker SV. Colorectal neoplasia in juvenile polyposis or juvenile polyps. Arch dis Child 1991; 66: 971-5.

99. O'Riordain DS. O'Dwyer PJ, Cullen AF, McDermott EW, Murphy JJ. Familial juvenile polyposis and colorectal cancer. Cancer 1991; 68: 889-92.

100. Stemper TJ, Kent TH, Summers RW. Juvenile polyposis and gastronintestinal carcinoma. Ann Dis Med 1975; 83: 639-46.

101. Grigioni WF, Alampi G, Martinelli G, Piccaluga A. Atypical juvenile polyposis. Histopathology 1981; 5: 361-7.

102. Rozen P, Baratz M. Familial juvenile polyposis with associated colon cancer. Cancer 1982; 49: 1500-3.

103. Jarvinen H, Fransilla KO. Familial juvenile polyposis coli; increased risk of colorectal cancer. Gut 1984; 25: 792-800.

104. Le Dai J, Turnacioglu KK, Schutte M, Sugar AY, Kern SE. Dpc4 transcriptional activation and dysfunction in cancer cells. Cancer Res 1998; 58: 4592-7.

105. Sener RN, Kumcuoglu Z, Elams N, Oyar O, Tugran C. PeutzJeghers syndrome: CT and US demonstration of small bowel polyps. Gastronintest Radiol 1991; 16: 21-23.

106. Starink TM, van der Veen JP, Arwert F, de Waal LP, de Lange GG, Gille JJ, Eriksson AW. The Cowden's syndrome: a clinical and genetic study in 21 patients. Clin Genet 1986; 29: 222-33.

107. Salem OS, Steck WD. Cowden's disease multiple hamartoma and neoplasia syndrome. A case report and review of the English literature. J Am Acad Dermatol 1983; 8: 686-96.

108. Starink TM. Cowden's disease: analysis of fourteen new cases. J Am Acad Dermatol 1984; 11: 1127-41.

109. Chen YM, Ott J, Wu WC, Gelfand DW. Cowden's disease: a case report and literature review. Gastrointest Radiol 1987; 12: 325-9.

110. Brownstein MH, Mehregan AM, Bikowski JB, Lupulesen A, Patterson JC. The dermatopathology of Cowden's syndrome. Br J Dermatol 1979; 8: 686-96

111. Requena L. Gutierrez J. Sanchez-Yus E. Multiple sclerotic fibromas of the skin. A cutaneous marker of Cowden's disease. J Cutan Pathol 1992; 19: 346-51.

112. Williard W, Borgen P, Bol R, Tiwari R, Osborne M. Cowden's disease. A case report with analysis at the molecular level. Cancer 1992; 69: 2969-74.

113. Carlson GJ, Nivatvings S, Snover DC. Colorectal polyps in Cowden's disease multiple hamartomata syndrome. Am J Surg Pathol 1984; 8: 763-70.

1 14. Taylor AJ, Dodds WJ, Stewart ET. Alimentary tract lesions in Cowden's disease. Br J Radiol 1989; 62: 890-2. 
115. Hauser H, Ody B, Plojoux O, Wettstein P. Radiological findings in multiple hamartoma syndrome (Cowden disease): a report of three cases. Radiology 1980; 137: 317-23.

116. Ortonne JP, Lambert R, Dandet J, Berthet P, Gianadde E. Involvement of the digestive tract in Cowden's disease. Int J Dermatol 1980; 19: 570-6.

117. Lashner BA, Riddell RH, Winans CS. Ganglioneuromatosis of the colon and extensive glycogenic acanthosis in Cowden's disease. Dig Dis Sci 1986; 31: 213-16.

1 18. Nelen MR, Padberg GW, Peeters EAJ, Lin AY, van der Helm B, Frants RR, Coulon V, Goldstein AM, van Reen MMM, Easton DF, Eeles RA, Hodgson S, Mulvihill JJ, Murday VA, Tucker MA Mariman ECM, Starink TM, Ponder BAJ, Ropers HH, Kremer H, Longy M, Eng C. Localizazion of the gene for Cowden's disease to chromosome 10q22-23. Nature Genet 1996; 131: 114-16.

119. Li J, Yen C, Liaw D, Podsypanina K, Bose S, Wang SI, Puc J, Miliaresis C, Rodgers L, McCombie R, Bigner SH, Giovanella BC, Ittmann M, Tycko B, Hibshoosh H, Wigler MH, Parsons R. PTEN a putative protein tyrosine phosphatase gene mutated in human brain breast and prostate cancer. Science 1997; 275: 1943-7.

120. Di Cristofano A, Pesce B, Cordon-Cardo C, Pandolfi PP. PTEN is essential for embryonic development and tumor suppression. Nat Genet 1998; 19: 348-55.

121. Chi SG, Kim HJ, Park BJ, Min HJ, Park JH, Kim YW, Dong SH, Kim BH, Chang YW, Chang R, Kim WK, Yang MH. Mutational abrogation of the PTEN/MMACl gene in gastrointestinal polyps in patients with Cowden disease. Gastroenterology 1998; 115: 1084-9 